\title{
Chapter 10 \\ Successful Ageing: An Opportunity \\ and Responsibility for All
}

\subsection{Individualistic Way of Achieving Successful Ageing}

The term "successful ageing" has gained much popularity among scientists, researchers, politicians and geriatricians (such as myself) when referring to the older adults in the last three decades [1].

However, when I enquired about what "successful ageing" meant to an octogenarian or a nonagenarian, there was hardly any awareness about this term among them. Although most people would like to be physically, psychologically and financially independent, feel satisfied with their life and die in a dignified way, to most octogenarian "life is a path that they have almost travelled, an experience that they have already experienced". For many people, life is just a component in the cycle of birth and death.

When I simplified the questions and asked about their life satisfaction, quality of life and late-life participation as per their ability, in the context of social and family, the respondents were mostly clueless. Prevalent notions such as "ageing successfully is a destiny, which cannot be modified" or "ageing means disability and dependence, with an uncertain future about dignity and autonomy" influence the attitude towards the sunset years. So, what about the preparation for successful ageing from middle life or late adulthood (60-75 years)? What about increasing physical and cognitive reserve, thereby building a high intrinsic capacity?

There was a paradigm shift, particularly in societies such as Japan, Sweden, the USA, the UK and a few European countries - which have been preparing for active ageing for the last couple of decades - towards disrupting ageing through optimization of mental and physical involvement and minimizing functional loss. Thus, understanding about successful ageing from an individual's perspective within the local sociocultural milieu is important. 
It was a Sunday morning when I was flipping through the pages of a newspaper and saw a column by Ruskin Bond, a noted writer in his 80 s. He had written, "I am a peculiar person, liable to be stuck in a position for hours if I try too ambitious an "asanas"" [2]. In his column, he had tried to convey the message that what matters most in life is how you conceive it, how you enjoy your work and how you keep yourself busy via meaningful engagement. As he mentioned, "I must say, I am a little surprised because I don't come from a long-lived family nor have I bothered to take care of myself health wise. I hate all forms of physical exercise".

Fortunately, active ageing and longevity is not just an issue of pedigree and genetic influences from the family. Despite recent advances in molecular biology and genetics, certain mysteries that control human lifespan are still not understood. Traditional theory suggests that family history plays an important role. Davidovic et al. discussed the role of genetic instability in ageing and dynamics of ageing process because of sequential switching off and on of certain genes [3]. As per heritability calculations, $15 \%$ to $20 \%$ of variation in lifespan among humans can be attributed to genetic factors [4].

Mr. Bond does not practise any yoga or exercise of any form. But he has a wonderful quality of falling asleep at any given moment at any place he wants, which is the secret of his happiness. It also signifies peace of mind and maintenance of the sleep cycle. His confident denial of programmed ageing practice signifies his satisfaction with his current activities without any regret. In his own words, "Perhaps, I am meditating in a wrong place. My little room with morning sun on my desk is really meant for writing and sleeping. In between naps, I write down stories or essays".

Probably, the secret of his successful ageing was his aspiration, his meaningful engagement, support system of his adopted family, his cognitive excellence and the intellectual inquisitiveness. Thoughtful writing is a brilliant exercise for the brain's cortex, particularly the motor area, which also controls the movements of the hand. Moreover, he exercised his fingers by writing and learning new things to improve neuronal regeneration, which helped him in nurturing his right hemisphere [5].

Writing is nutrition to the brain. It is an exercise for the motor coordination of the brain. Studies have suggested that mere imagination about working out with your limb is beneficial [6]. Ageing is a process of turning young adults to older adults with a cumulative deficit in multiple domains. Ageing may be viewed as a coordinated malleable process but surely not a disease [4]. As a geriatrician, I would say that the story of Ruskin Bond in his $80 \mathrm{~s}$ is a model of successful ageing. Rowe and Kahn's model mentioned successful ageing as (1) absence or avoidance of disease or risk factor of a disease, (2) maintenance of physical and cognitive function and (3) active engagement with life such as mental and psychosocial element. Mr. Bond has all these factors favourable towards him not by preparation or choice. He had the perception of "subjective wellbeing (SWB)". The feel-good factor and a coefficient of satisfaction with life, with or without physiological decline, would play a major role in successful ageing. As stated by Cantor et al., a person should select the right task at the right time, living the life they want to live [7]. So the participation in life and positive SWB depend on how far the selected activity meets the wishes 
once an ideal of the person (self-concordance) is met. However, he can pursue that goal in a way that is intrinsically valued. Nevertheless, pursuing tasks that are intended to fulfil others' desires and expectations may not have a positive effect on SWB [8].

The life course theory understands ageing as an outcome of how you have lived your life throughout. It is like determining the longevity of a car based on how its owner maintain it, the driver's skills and how frequently its engine is serviced.

\subsubsection{Aspiration Index and Active Ageing}

In March 2012, I remember meeting Mr. Mohan Lal who had attended my OPD.

"Namaste! Doctor saab", he sat and started explaining his problem, "I am a little slow, have disturbance in sleep, and I feel tightness in my leg when I try to walk. I have been facing these problems for the last six months. Previously, I had high blood pressure, sugar, and heart problem, for which I am on these medications".

I noticed that he was on three medicines for the heart, two for hypertension, three for diabetes, two for multivitamins, one for calcium, one medicine for gas and a sleeping pill. After evaluation, I came to know that he was suffering from early Parkinsonism as evidenced by loss of hand swing and slight difficulty in gait, but there was no rigidity (stiffness of the hand or leg) or bradykinesia (overall slowness). However, he had non-motor features like sleep problem and anhedonia (inability to feel pleasure in normally pleasurable activities).

In the second consecutive session within a span of 2 weeks, I reduced his pill burden from 18 to 7 . In fact, I reduced his blood sugar medicine as his HBA1C was 5.4 , which was much less than the normal recommendation for elderly people. As per the 2018 American Diabetes Association recommendations for management of diabetes in older adults, for a healthy older adults having few comorbidities, such as Mr. Mohan Lal, but with intact cognition and functionality, a reasonable goal of HBA1c should be $<7.5$, whereas the target for older adults with mild to moderate cognitive impairment HBA1C should be $<8.0$. On the other hand, older adults with complex diseases, severe dementia, dependence for activity of daily living with limited life expectancy, a reasonable goal of HBA1c should be $<8.5$ [9]. Furthermore, I reduced his medication for the heart, which he had been taking for the past 30 years, while gradually stopping his multivitamins and PPI (proton-pump inhibitor). The sleeping pill (alprazolam 0.5) was gradually tapered and stopped as such pills in any form would do more harm as they increase the chance of drowsiness, light-headedness, memory loss and fall or having an accident. Moreover, they increase the need of unexpected hospitalization too [10]. I was addressing his concern of being on "too many pills".

I explained to him, "Mr. Mohanlal, you are suffering from a degenerative disease of the brain where gradually an individual develops various neurological symptoms like tremor in hands, slowness in movement and balance problem". 
"Why does it happen?" he asked.

"It is probably a problem with the release of neurotransmitters (dopamine) in the brain".

"There must be some treatment for this".

"Yes, I am prescribing".

After a pause, I continued, "Unfortunately, the disease is progressive and slowly it affects day-to-day activities".

His immediate response was "How long will I survive?"

I noticed that despite suffering from multimorbidity and incurable diseases like Parkinsonism, Mr. Mohan Lal was attentive, confident and eager to understand his disease. He continued, "I have to complete my job. I have full faith in you. You have reduced my medication and I am feeling much better now. I am sure that you can stop my disease and I would do better".

"I hope it would work for you. We can't predict how your disease would progress in your case. It might progress slowly or very slowly. We have very good drugs that would help you. Physiotherapy has a major role to play, which you are already taking". I tried to assure him.

"What do you do for your living?" I further probed.

"I was a farmer. I used to supervise the work of our ancestral agricultural property". He told me, "But I left that job to my younger son 10 years ago".

"But now?" I enquired.

"Actually, it was his mission", he continued after a pause, "of my elder son, Veer, who died at the age of 50 because of blood cancer just a month back. He wanted to start a school for girls at our ancestral property. You know, girls are still neglected in this country. They are only meant to be a daughter, wife, and mother, and serve the male dominant society. He wanted to change this notion. I have to start the school".

I could feel his zeal to live and fulfil the dream of his son. He was full of energy despite all odds. "I would sell off my ancestral property to start the school. I have no regrets. You know doctor, my daughter-in-law is also a teacher and she is planning to quit her job and to dedicate her time in building and running the school. We would raise funds from nearby villages. We want to start at the primary level. Primary education is still not sufficiently provided in most of the villages in this country".

I was astonished at the level of his planning, aspiration (both intrinsic and extrinsic), life course and determination.

I even started believing that Mr. Mohan Lal could change his destiny. He was responding well to the dopamine agonist (ropinirole $0.5 \mathrm{mg}$ twice daily) and lowdose melatonin $(3.0 \mathrm{mg})$ for his sleep problem. Studies have suggested that melatonin could be the most effective drug to manage sleep problem in this case [11]. It could be useful for managing motor symptoms of Parkinsonism too [12]. He was practising Nordic walking and physiotherapy under the supervision of the physiotherapist. 
As stated by Baltes et al., every individual, including the older adults, have the possibility to attain personally and culturally valued goals. However, those who suffer from multimorbidity usually reduce their daily activities; therefore, they miss the opportunity to reach the goal [13]. This fact might be true for many older adults but not for Mr. Mohan Lal. His determination and love for his son have made his psychophysical potentialities much more stronger than expected. This phenomenon could be explained by emotional intelligence in its highest state, which is defined as "flow". He was completely immersed in his goal-oriented task [14].

He gathered money from other villagers, obtained permission from respective authority and, in a year, started primary school with a holistic approach up to class $\mathrm{V}$ with a capacity of 100 young girls as students. He used to give me updates about his achievements.

He was following my prescription and religiously executing his physiotherapy regime. Studies have suggested that Nordic walking [15] and physiotherapy [16] help in stabilizing gait in patients suffering from Parkinsonism as well as slow its progression. Mr. Mohan Lal would visit me every 3 months. I had asked him to call me whenever required. Every time he calls, he surprised me with his energetic but shaking voice, "Sir, I am feeling much better, busy with the administrative work of my school these days. I am doing physiotherapy regularly the way physiotherapist has suggested. My mind is active and trying to expand the school, but I have problem in writing and walking. Can I come for a visit?"

Compared to most of the elderly patients, this conversation indicated the positivity and zeal to live and do something for others. Mr. Mohan Lal was never a health conscious individual. He did not restrict his calorie, neither he did any exercise ever. He fought off the worst situations of his life with emotional intelligence. Probably he could convert his emotional distress to guide and behave in certain ways through which he could not only fulfil his dream but did it effectively.

Others start discussions with some complaints, which personify their trait. In fact, Mr. Mohan Lal never complained to me about his minute ageing changes like decrease in sleep hours or anorexia of ageing. His anxiety status improved; as expected, there was no anhedonia in the last 4 years; however, his disease (Parkinsonism) had progressed a lot. His gait had become more unstable and he had frequent falls. I had to increase his medicine as there was rigidity (dopamine agonist and Syndopa). We took the neurologist's opinion in AIIMS for further management who supported the same medication.

He had developed tremors in his left hand, which had now progressed to the right and caused trouble in performing fine motor activities like signing a cheque.

He visited me in March 2017, and with immense pleasure, he handed me a box of sweets, "Doctor, my students are doing very well so am I. But, do you feel that I need some more medicine to stop the disease? I know my disease has progressed a lot but still I want to live".

In the evening, when I removed the box of sweets from the table, I found a letter. 


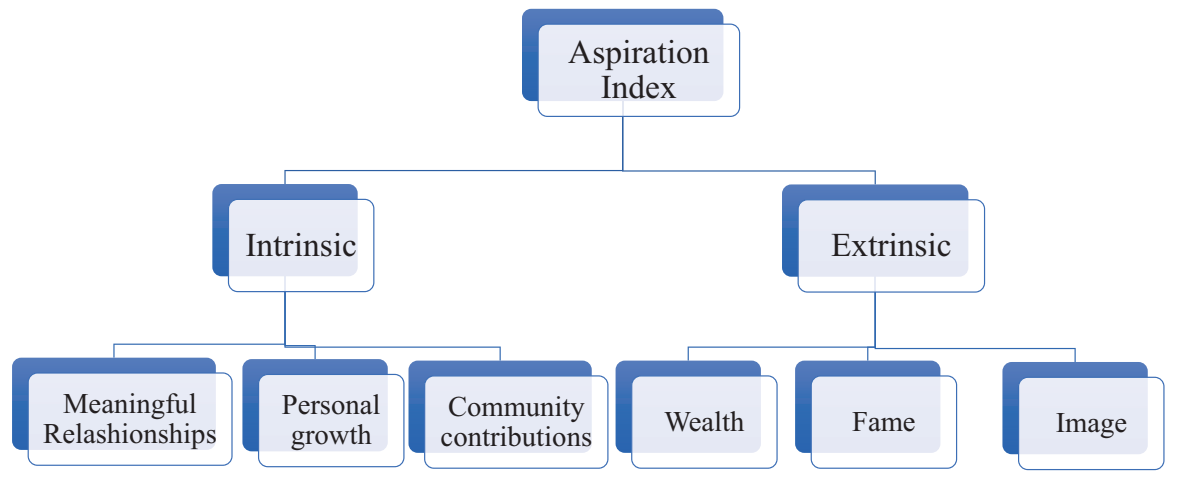

Fig. 10.1 Aspiration index. (Source: Author)

The letter read as, "Doctor, I am not greedy, but I have set another goal for myself. I have to extend the school till upper primary and secondary, which was what my son had wished for. I owe you the success and thank the motivation that you have given me in all these years; I feel rejuvenated after talking to you". He had the interesting quality of sharing the credit of success with others. "My daughter-inlaw and younger son are doing extremely well and my society has supported me a lot. In fact, the primary students are doing great".

While researching the various models of successful ageing, the aspiration index plays a major role; however, it has not yet been explored and discussed much till date.

The aspiration index refers to people's life goals and has two domains: intrinsic and extrinsic (Fig. 10.1).

For Mr. Mohan Lal, his two intrinsic factors were meaningful relationships and community contribution; however, his major motivation was his love for the elder son. We obtained results similar to those published by Kasser and Ryan, in which the authors had mentioned that while there was a positive association between intrinsic aspirations and mental health indicators, the extrinsic outcomes were negatively associated with mental health indicators [17]. This is a probable explanation of why Mr. Mohan Lal, despite suffering from advanced stage of Parkinsonism, with low educational attainment, did not suffer from cognitive impairment. Furthermore, studies had shown that self-reported attainment of intrinsic aspirations was positively associated with health, although the attainment of extrinsic aspirations was not [18].

Mr. Mohan Lal, who hailed from a middle-class family that had minimal education, with age-related morbidity and progressive degenerative disabling disease, was just like millions of elderly Indians. However, his belief in himself that he could achieve his goal, intrinsic aspirations, empathy, work in "flow", cognitive effort and agreeableness stimulated him to be psychologically healthy and enjoy successful ageing even when he was suffering from chronic progressive disease. Furthermore, he had the sociological, emotional, physical and family support with him. 
It is to be noted that there is no set pattern of how to age successfully and how to maintain subjective wellbeing via multidimensional dynamic processes.

\subsubsection{Conscientiousness and New Possibilities}

One of my distant uncles from West Bengal, Mr. Tarun Mukhopadhyay, who is a retired school teacher and a chain-smoker and fortunately did not suffer from any comorbidities, was spending his days catering to his grandson who was studying in Class IV. Mr. Tarun, an extremely successful teacher, continued teaching after retirement and helped many students to be successful. However, he stopped after his $70 \mathrm{~s}$ as he lost his interest in his activities, and none of his family members could make out the reason.

Since my childhood, I have known him as a person with alpha factors with low levels of neuroticism (emotional stability) and high levels of conscientiousness. He preferred goal-oriented and organized work and had a disposition to be responsible and diligent.

It is to be noted that the Baltimore Longitudinal Study on Aging (BLSA) is considered as the most definitive study for personality traits. While analysing long-term personality data, BLSA research team learned that, in fact, personality of an adult does not change much after the age of 30 years. Hence, cheerful people and assertive ones in their 30s will likely be the same even when they are of 80 years. This result contradicts the popular belief that ageing people naturally become cranky, depressed and withdrawn. The study to evaluate individuals between 19 and 80 years of age for a period of more than 12 years was conducted by Costa and McCrae [19]. The study specifically measured five factors that affect personalities such as neuroticism, extroversion, openness to experience, agreeableness and conscientiousness. Conscientiousness yields stability across a lifespan. Furthermore, trait stability was particularly characterized by individuals after the age of 30 years [20].

The results of meta-analysis of genome wide association studies (GWAS) of personality found one single nucleotide protein (SNP), which was associated with conscientiousness across multiple samples. Terracciano observed that there were many intervening factors between a SNP and a complex phenotype such as trait conscientiousness [21]. Moreover, the interaction between nature and nurture was rather an explicitly proven result [22].

While considering the association between personality, successful ageing and SNP, it was noted that personality is categorized into temperament with four dimensions and character with three dimensions: self-directedness (SD), cooperativeness and self-transcendence (ST) (Cloninger's theory). It is assumed that these temperament dimensions depend upon secretion and metabolism of neurotransmitters in the CNS, i.e. dopamine, 5-HT and norepinephrine. As temperament is heritable, it is fully manifested during infancy and involves preconceptual biases for perceptual memory and habit formation [23]. 
Some dimensions and sub-dimensions of the Temperament and Character Inventory (TCI) were correlated with gene polymorphism. A study by Aoki and his team [24] states that 5-HTT $3^{0}$ UTR gene polymorphism had significant association with inherent traits such as self-transcendence, transpersonal identification and spiritual acceptance. Individuals who had a low self-transcendence score might be unimaginative, controlling, materialistic, possessive and practical, while those who had a high self-transcendence score might be self-forgetful, transpersonal, spiritual, enlightened and idealistic [25].

At 70 years, there were not many jobs for Mr. Mukhopadhyay. His grandson, who was now in Class $\mathrm{V}$ and mostly engaged with his mother, went to different classes like music, painting, etc. which my uncle never liked. He was always bound by rules, self-contained and disciplined; however, open to experience and agreeableness was not a feature of his personality. He truly had a passion for writing poems in Bengali. I met him at a family celebration in 2014 and tried to nudge him, "Why don't you explore the potential of writing poetry?" Interestingly, he was exploring that process itself. My stimulation ignited his latent desire, and he began evolving by spending time in writing. He published his poetry, which was appreciated by many learned poets of Bengali literature.

I met him once again during Durga Puja in October 2017.

"How are you doing?" I asked.

"I am doing great and reading a lot of books, writing a few poems too". He cheerfully replied.

"Oh! Great". I was flipping through his writings, which were so rich in language.

"Uncle, have you stopped smoking?" I probed a bit further.

"Yes, what your medical science couldn't do, my writing did". Even at the age of 73 , he wanted to achieve successful ageing and had stopped smoking because he thought it was harmful, would affect his writing, make him cognitively impaired and cause a heart problem, all of which I had cautioned him earlier.

"What about your friend circle?"

"It is all a waste of time. I do not have time. I have to write so many books. I feel, probably, I have wasted a lot of my time. I should have started earlier".

A person with an active conscientiousness could modify their unhealthy habit at any age even at the age of 73 and get healthy to contribute to the society.

So, he had found his goal and had aspired to prove himself. "When I will not be there, I want to give something to the society to understand how injustice and disharmony is increasing in society. How the wealthy are becoming wealthier and the poor are becoming poorer. You see I am trying to explore the Mahabharata from a different angle". He recited his own poem on the impact of the Mahabharata on the modern society. He was discussing the importance of women empowerment in his writing.

My uncle had been a small eater throughout his life. Studies suggested that diet restriction increases the lifespan even if it is started during adolescence. However, there are limited studies that have led to less successful results when diet restriction is started in late life or after adult life. So, if somebody is surviving up to 80 years and starts diet restriction after 40 years, the result is still unknown. As geriatricians, 
we do not recommend diet restriction, particularly protein restriction. Methioninecontaining protein restriction may be harmful at the age of 80 . When sarcopenia sets in and the muscle requires more protein, it will have a role reversal at that time. However, uncle had little time to regularly exercise, which has been cited in all literature, to have a beneficial effect considering the mortality, morbidity, hospitalization and development of dementia.

"I go for an occasional walk, I am immensely happy, I am satisfied, I do not waste my time in criticizing others or in playing cards, I will continue to write".

When a person becomes utterly absorbed in what he is doing, he pays undivided attention to the task; even his awareness and actions are dedicated to the task. It becomes ultimate tool in managing the emotions in the service of performance, and then learning the act itself is what motivates the person.

Indeed there is no specific model to explain that this is the only path that can make you successful; it has to be created by each individual. Geriatricians and researchers should play a role in educating elderly people and their younger family members for successful ageing as a life course perspective. It is difficult to achieve this after reaching the age of 80 ; however, the preparation should be started early. In fact, meaningful engagement of flow is definitely a well-studied path.

\subsubsection{Blue Zone of the Earth: The Life Lessons}

During a talk at a society in Sector 17A, Noida, I asked a question: "Who would like to survive 100 years?" In reply, only 2 of 200 older adults said they would like to actively age till the age of 100. Many responded by saying, "I don't want to live so long at the mercy of others", "100 years means invariably there would be disability, dementia or deconditioning", or "The earlier I die, it is better, I have so many co-morbidities".

I continued my discussion about the Blue Zone on Earth, which consists of five places in various countries such as Loma Linda in California, Sardinia in Italy, Icaria in Greece, Okinawa in Japan and Nicoya Peninsula in Costa Rica, where an average human being's lifespan is 100 years [26]. The common factors of these Blue Zone people were that they stayed in joint families, engaged meaningfully until their death, ate plant-based diet, are non-smokers, consume alcohol occasionally and engaged in constant low-level physical activity such as hiking, gardening and farming. Moreover, they were socially active, integrated into their communities to contribute in any form, and they are satisfied with their life and have a fantastic quality of life thorough out their life.

A little more investigation on Blue Zone population shows that their primary is diet $95 \%$ plant-based. They tend to eat meat only around five times per month.

A number of studies suggested that avoiding meat can significantly reduce the risk of death from heart disease, cancer and many other diseases [27], whereas eating more than five servings of fruits and vegetables a day can significantly reduce the risk of heart disease, cancer and death [28]. 
In the Blue Zones, the diets are typically rich in legumes like beans, peas, lentils, chickpeas, rich in fibre and protein and nuts which are great sources of fibre, protein and polyunsaturated and monounsaturated fats. It was noted they prefer whole grains rich in fibre and associated with reduced colorectal cancer and death from heart disease.

They often eat fish which is a good source of omega-3 fats, which are important for the health of the heart and brain. Eating fish is associated with slower brain decline in old age and reduced chances of heart disease.

The people of Okinawa tend to follow the $80 \%$ rule, which means that they would stop eating when they feel $80 \%$ full, rather than eating till there is no space left in stomach. This prevents them from eating too many calories, which is the cause of weight gain and chronic disease restriction.

In the Blue Zones, people don't exercise purposefully by going to the gym, but they incorporate it in their lifestyle. They are living on steeper slopes in the mountains and walk longer distances to work, farming animals.

They get sufficient sleep of $7 \mathrm{~h}$ at night and 30 min naps during the day. They have strong social support, thereby reduced rates of depression.

In most of the Blue Zones, grandparents often live with their families (intergenerational living). Studies have shown that grandparents who look after their grandchildren have a lower risk of death [29].

They consume alcohol, mostly red wine, in moderation, which contains a number of antioxidants from grapes. It has been reported that consuming one to two glasses of red wine per day is particularly common in the Icarian and Sardinian Blue Zones. It has been suggested that antioxidants prevent damage to DNA which is associated with ageing process, and hence, it might be important for longevity. As per the reports available, drinking moderate amounts of red wine is associated with a slightly longer life. Furthermore, the individuals who consumed 5 ounce $(150 \mathrm{ml})$ glass of wine every day for 6 months to 2 years had significantly lower blood pressure, lower blood sugar, more "good" cholesterol and improved sleep quality. However, these benefits are only seen for moderate alcohol consumption. These studies also showed that higher levels of consumption actually increase the risk of death [30].

The current recommendations from the Physical Activity (PA) Guidelines for Americans suggest a minimum of 75 min of vigorous-intensity or $150 \mathrm{~min}$ of moderate-intensity of aerobic activity per week [31]. A study conducted on 661,137 people revealed that there was $20 \%$ lower risk of death among the people who were doing the recommended amount of exercise as compared to the ones who did no physical activity [32].

Happiness in and with others could be one of the prerequisites for long and healthy living. Ms. Meena Dixit, from Ghaziabad, started a laughter yoga club, an organization that mitigates the agony of late-life, combining laughter and yoga, unique format to transfer positive energy to others. Along with positively changing their own behaviour, they also try to imbibe a positive attitude in anybody in their vicinity or connection. They not only work within their colony but also visit old-age homes, orphanages and schools in their fixed schedules. Ms. Dixit ran an art and craft centre also. 
"We call the older people from their family, try to give them emotional social support, change their attitude towards physical exercise and yoga, try to see participants on a continuous basis, we try for one person in about 6 weeks at a stretch and once they continue with us for 6 weeks they become a lifelong activist who promote physical activity in any form which has immense value in wellbeing of the individual". Ms. Dixit continued, "They enjoy the activity they do, it could be laughing yoga, it could be visiting an old age home and interact with them, thereby, increasing their social cohesiveness".

Her advice "Happiness is contagious, spread it!", was a keen insight.

An individual's preference to choose an active or inactive spare time job is equally important. Many older adults may like to spend their time only playing cards, watching television, and gossiping.

My mother usually remains busy in her activities, such as managing her grandchildren, family and coordinates between various care providers of our family. We stay in a lush green campus with a lot of space for walking.

"Mom, why don't you walk?" I asked her one day.

"I don't have time" her reply.

"You can walk when Rani (my daughter) is sleeping and Pratik is studying".

"I have to knit a sweater for my Rani. This time winter seems to be very harsh. The care providers you have appointed is not at all good. They don't take good care of your children, so I have to monitor them. They don't prepare good food for you".

She is only 61 years.

"But you know, to be healthy you should walk, do some exercise on regular basis".

"Yes, I know. But I don't enjoy walking. I will walk when I would be 70 plus. I know it would be difficult for you to take care of me if I am bedridden. I will take care of myself, don't worry". She said in a commanding voice.

She doesn't go to any temple, neither enjoys going to mall nor cinema hall.

\subsection{Spirituality and Successful Ageing}

My aunt, a 75-year-old widow, staying alone in West Bengal, often visited her son, daughter-in-law and 10-year-old grandson who stayed in Hyderabad. But she didn't like to stay with them even though her son and daughter-in-law are extremely cooperative. She believed that life would be complete only and only when we realized God and die at the lotus feet of God. She visited the nearest Ramakrishna temple every morning and evening, cleaned the area, distributed Prasadam to the devotees, was financially well-off because she had a good pension from my uncle. She believed spirituality and prayers to be the best healing mechanisms. According to her, prayers create bonding with higher powers; we gain forgiveness, strength, positive attitude and health and inspire hope. Recently researchers had published data on spirituality and successful ageing. Spirituality had been considered as another dimension of healthy ageing [33]. 
It is all about preparation. Preparation for successful ageing starts from the very first day of birth. Adoption of healthy practices like diet restriction, physical activity, managing stress, prevention of chronic diseases, setting up of personally valued goals, avoiding negative perception, accepting the random events of life, modifying the personality, from neuroticism to let go approach and selfless Karma, helps in achieving and maintaining successful ageing. Those who had not prepared from their early years try to follow: "Go out a lot and enjoy life, take it day by day, enjoy what you can, have good health, that is more important than anything else. Keep active - while your legs are moving, get out on the. You contribute to the society and get actively involved to be happy and satisfied" [34].

It is not always be possible to enjoy good health with meaningful engagement like Mr. Mohan Lal or like Dr. A.P.J. Abdul Kalam, the former President of India and a Scientist, a lifelong disciplinarian. Every person has a unique destiny. If we live up to 70, 80 or 90 years, how do we cope with the frailty of body and mind in an ever-demanding society?

"I have now become too old and disturbed by invalidity. While writing, my hands tremble. I cannot remember anything, nor can I see or hear properly. Still I write and this is a great wonder", as said by Srila Krishnadasa Kaviraja Goswami, a 70-yearold author, who wrote Chaitanya Charitamritya, the life and teachings of great Saint Shri Chaitanya Mahaprabhu.

An individual's spirituality as an important aspect within health [35], and spirituality improves wellbeing assisting individuals through transcended suffering, pain and despair and coping with illness [36]. The perception that God in any form is somebody who cares for me, blesses me, loves me, gives me strength and forgives me is something that equates to the love, courage and blessings of parents in childhood.

This was certainly true in the life of Srila Prabupada who went to the USA to spread Krishna consciousness at the age of 70, who was not known to the world till that time. He suffered two episodes of heart attack on his way. But it didn't deter him from going to the USA for the first time in his life with neither any contact nor preparation. His intrinsic aspiration for community contribution was very high. His faith in the Lord Krishna made him determined, stress-free and full of hope. In the last 11-12 years of his life, he spread the message of peace and harmony globally. This can be one of the best examples of successful ageing where a person explored his best potential at the age of 70 and proved to the world that productivity had no age bar.

\subsection{Adopting with Random Events}

Ms. Saigal, who was doing extremely well with her play school in Lucknow, had to shift after the demise of her son to Gurugram (Haryana) to support daughter-in-law and two grandchildren. She was active even at the age of 76 and was a popular 
teacher in Lucknow. She was teaching 50 school children from economically weaker section free of cost and aspired to expand her play school to the primary level. Initially she was depressed because of the demise of her young son of 40 years in a car accident and had to leave her peer group and profession from Lucknow where she was living for the last 40 years. But, after 5 years in Gurugram, she had modified her goals and adopted the metropolitan culture of Gurugram and grooming. Her grandchildren were in standard III and VI. Now she would enjoy dropping her grandchildren to school and had joined a piano class along with the elder grandson. She would visit the temple frequently and was writing her autobiography. But she continued to maintain her quality of life as per the theory of satisfaction paradox. The relative continuity of QOL over old age is associated with satisfaction paradox [37] which highlights the adoption mechanism used by individuals to review their own standards and values as their situation evolves or changes.

\subsection{Preparation Is Not Similar for Rural Elderly}

While elderlies in urban centres and metropolitan cities in India are adapting to an active and self-engaging lifestyle in their later years, it is in rural India that lies a greater challenge as awareness about health and merits of physical activity has not been spread as it should have been.

Last Durga Puja when I visited my village, I was talking to Mr. Tapan, a senior member of our village who was over 60 years old. He told me, "I get good meals, in both morning and evening cooked by my daughter-in-law. I have high blood pressure, sugar, and heart problem, so I visit the doctor, once in every three months, who stays 100 miles away from my village. So, for me this is a bonus life. I have survived one heart attack and the next one probably would kill me".

"Why don't you walk?" I asked.

"I used to walk. I had a heart attack while I was going to the pond. Now I have knee pain. The doctor said I need to change it. But I don't want to do that, I am 67 and my father had died at the age of 70. So, I have three more years to go".

They believe that crossing 60 is enough; they have minimum years to live, immobility, mostly restricting them to home. They only mobilize themselves for any religious activity.

Sometimes physical activity becomes conditional, many a time owing to peer pressure. I was talking to one more granny of my village who was 85 years, severely depressed as she had lost her older son recently who was 62 in a road traffic accident. I went to see her and prescribed some medicine and suggested visiting the temple of the village regularly, considering that it would improve mobility and also a psychological outlet.

Her spontaneous response was, "Beta, none of my peer group is there in this village. Most of them passed away. Some shifted to city. With whom could I socialize? Now I will be happy only when I leave this planet, which is also not in my hand". 
Elderly ladies are comparatively more active than male counterparts because at least they manage their day-to-day activities within the house in a male-dominant society. Male older adults are not supposed to do household activities [38]. In India, older women are at a disadvantage as compared to older men with respect to the economic resources, health status, widowhood, etc. and men and women are clearly different, considering the environment in which they grew up and the traditional values they have imbibed from their families. The gender differences they had seen during socialization in adult life create specific opportunities or disadvantages in adopting life course perspective.

The result from the USA was also not encouraging in this regard. There are only $12.8 \%$ older adults who met the national objective combining aerobics and muscle strengthening activities among educated older adults. Chronic diseases among them mostly limit participation PA [39] like respiratory conditions such as COPD that cause breathlessness, cardiovascular conditions [40] and mobility gait and balance disturbance increasing the risk of fall. Falling and fear of fall among older adults is a matter of great concern globally [41]. Once they fall, it is very difficult to encourage them to go for walks or perform any form of exercise. As mentioned earlier, degenerative joint diseases or osteoarthritis of the knee, shoulder, etc., neuropathy, muscular weakness, vision/hearing problems, depression, incontinence, etc. further hinder physical mobility.

Avoiding physical activity can be due to cultural and generational norms. In my village, even an octogenarian woman should not be normatively visible outdoors and would restrict herself at home. In fact, there are few avenues of physical activity in village communities.

Lack of knowledge about appropriate physical activity may also have a detrimental effect, such as increased vulnerability to injury when inappropriate activity is selected [42].

Being too busy is a common reason cited in older adults for not participating in physical activity [43], especially in the business communities and educated community who are still engaged in a profession. Socialization helps a lot as it enhances the experience and increases motivation. When my mother is at her native place, she walks everyday with her peer group, sometimes just to accompany them while catching up.

\subsection{Regular Physical Activity and Healthy Diet: Needs Behavioural Motivation (Fig. 10.2)}

Elderly care physician or therapist should spend some time for motivational interviewing to assess their client about changing their health behaviour. Usually the doctor or therapist directly begins the communication with the client by giving advice, often complex for clients or too overwhelming in its content and amount, therefore not heard properly [44]. 


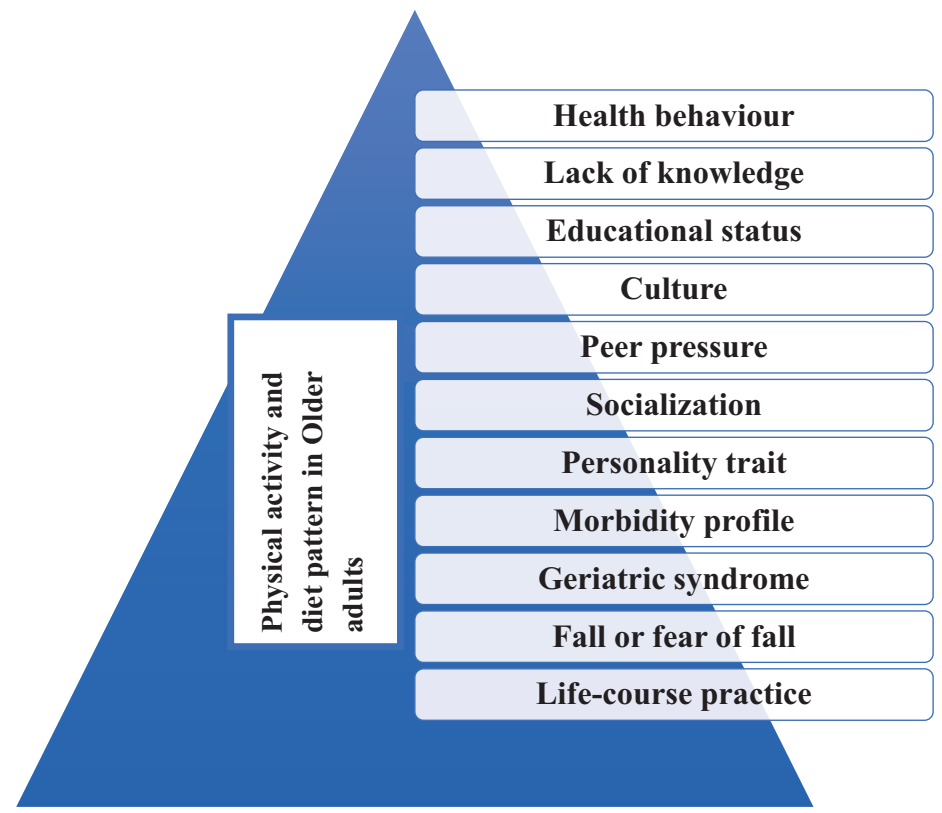

Fig. 10.2 Factors influence physical activities and diet pattern in older adults. (Source: Author)

Mr. Tapan had been complaining, "My heart doctor initially told me not to do anything, but after the heart operation he mentioned about brisk walking and some resistance exercises which I didn't understand at all. How can I do these exercises with my painful knee? He didn't bother to explain".

Ideally PA should be individualized and be consistent with participant's goals and values and accomplished by employing empathy, one of the most delicate principles of motivational interview (MI). The goal of MI is to attain an initiation and commitment for change that is collaborative, evocating and honouring of client's autonomy sort by both the client and the practitioner [45].

First step in MI is to listen from the client verbally "the reasons to change and to be more physically active". Once learned well, MI can be used effectively in a short amount of time allotted for most of this visit. One study used telephone-only intervention for improving participation in PA among culturally sensitive AfricanAmerican socio-economically diverse community that resulted in clear benefit to the target group [46]. The sole purpose of MI is to bring behavioural changes, which are most difficult for any age group but specifically tedious and hard to achieve in the older adults. So as a doctor, when I talk to patients, I try to bring them to agree to increase their physical activity for a better SWB. First I would listen to them about not doing any physical activity, and then I would ask them about the solution, with essential information. One of my patients, Mr. Ramdas, an advocate from Chennai, complained that whenever he exercised in any way, he felt shortness of breath. He had been suffering from COPD for the last 20 years and weakness of 
lower limb muscle. We discussed his problem, and he was very keen on exercising as he understood that physical activity would enable him to be active. He also understood from literature that diet restriction helps in prolonging ageing. From the clinical point of view, I saw that he had weakness of the muscle, i.e. sarcopenia, where proteins have a major role to play.

"Sir, your COPD is well controlled now, but there is generalized muscle weakness, you can see shrinking of muscle, which is making you tired and causing breathlessness. Why don't you start some high protein diet in the form of egg white?" I suggested.

"No, no sir, I am a pure vegetarian. I also read that calorie restriction rather than protein restriction helps in prolonging life".

"You are right sir, but you have to balance between diet restriction and morbidity, and most of the studies that have been conducted are in lifelong diet restriction and not the diet restriction at late life or at your age". I reasoned with him.

Calorie-restricted diet delays changes in cells that proliferate continuously, such as gut epithelial cells and cells that can be triggered to proliferate such as lymphocytes. It delays ageing characterization by excess such as neoplasia and also those characterized by failure to proliferate such as immunosenescence. It causes agerelated changes at the tissue level and those involved in multiple cells and tissues lots of function and endocrine control circuit. A noted businessman of this country who was in his 80 s mentioned in his speech that the secret of his successful ageing was restricted diet. He used to follow a routine diet pattern, and his eating time was also fixed throughout his life, but he was always a small eater and did not discriminate among various foods. Plenty of vegetables, moderate protein and a good amount of carbohydrate were his usual food. The Institute of Medicine (IOM) recommended $10-35 \%$ protein, $45-65 \%$ carbohydrates and $20-35 \%$ fats [47] would be ideal for healthy diet regime [48, 49].

Plant-based organic diet is the best food to have a healthy late life and to keep various age-related degenerative diseases at bay. In 1996, Batke and his colleague reported that Ames dwarf mice in which a developmental defect in the pituitary gland impairs production of growth hormones, thyrotropin and prolactin show an increase of more than $40 \%$ in both mean and maximal lifespan compared to littermates with the normal allele at the same loci. But more importantly mice and rat feed approximately 30-40\% less food than they ordinarily consume and typically live up to $40 \%$ longer than freely fed animals. In mice calorie restriction expanded their lifespan, which was observed only if initiated at a very young age or in early adulthood (at 6 months) [4].

Mr. Ramdas was a bit depressed as well. He received dietary counselling and a diet chart. I assured him that the problem would be fine, his sarcopenia will improve and cardiac evolution will be normal. The best approach would be asking openended questions to understand the importance of exercise and diet for him and his physical activity behaviour and how keen he was about increasing his physical activity. 
He said confidently, "I understand that exercising would definitely help me. I know Dr. Chatterjee, this will also improve my muscle girth, strength, and my cognitive function. I am a little slow in court during these days, so I will increase my walking speed and do some exercise as suggested by your physiotherapist".

Growing evidences suggest that the cumulative deficit model of ageing is multifactorial where activation of chronic inflammation plays a major role which is subcellular and not manifest as organ-specific problems but makes an ageing body and mind vulnerable for disability and mortality. There is an inner protection system to fight against any foreign body. When it gets activated, it acts as a complex and important physiological response to external threats. There is relentless activation of immune system throughout the lifespan to attenuate or eliminate countless infections and injuries preventing them from becoming life-threatening.

Many older individuals who had not suffered from any obvious injury or infection have ongoing low-grade activation of inflammatory processes reflected by various inflammatory signalling proteins which include $\mathrm{C}$-reactive protein (CRP), interleukin 6 (IL-6), tumour necrosis factor-alpha (TNF alpha), interleukin 1 (IL-1) receptor antagonists, etc. Low-grade elevation of these biomarkers (blood markers) has evolved to be named as chronic inflammation. This chronic yet subtle process often presents itself in chronic diseased states without any clinical relevance to the patient or doctors as compared to acute inflammation which is associated with various conditions like acute exacerbation of COPD/abscess [4].

I had a detailed discussion with Mr. Ramdas as he was very keen to understand why I was so particular about physical exercise.

"Sir, every cell has a life span and it gets destroyed by an automatic process called apoptosis". I started explaining.

"Yeah! I know".

"There is also a reproduction of new cells".

"But I think that is a genetic thing".

"Yes, you are partially right. But you know increased secretion of inflammatory molecules (cytokines) from senescent cells have been observed in immune system cells, muscle cells, and few other cells of older adults. Senescent cells or the ageing cells are unable to undergo apoptosis or reproduction".

"That means, those cells are useless".

"Partially" I told him, "You know due to this cytokine production in the metabolically active muscle tissues- adipocytes which get replaced by fatty adipocytes gradually and lean body mass and strength of the muscle also gets reduced. This process is medically called sarcopenia".

"Oh! So that may be the reason for my lower limb muscles to have been shrunken".

"Could be. Fat cells secrete both kinds of molecules- TNF Alpha and IL-6".

"Is there any other mechanism?"

"Yes, there is! Within the cell there is mitochondria which also becomes dysfunctional due to oxidative injury. The free radicals actually stimulate one signal transduction cascade called nuclear transcription factor-kappa B (NFkB)" [4].

"What is that?" 
"I think, I should elaborate this a little more for your better understanding; the key gateway for the same is NF- $\kappa \mathrm{B}$. NF- $\kappa \mathrm{B}$ when activated by specific stress or inflammatory signal facilitates the expression of inflammatory mediators. You can say it is the stimulator of overall inflammatory pathway and its consequence with ageing. There is some role of dysregulation of hormones like testosterone, estrogen, dihydro epiandrosterone (DHEA) etc which usually prevent the cascade reaction of inflammation".

"Doctor, please elaborate any other implications of chronic inflammation other than muscle degeneration and sarcopenia". He was asking many questions, "Doctor, is there any other mechanism as to why the muscles get more and more thinner with ageing?"

"Molecular studies have shown that there is a direct link of down-regulation of Myo-D, a critical factor in skeletal muscle differentiation and repair with NF- $\kappa \mathrm{B}$ activation. Similarly, activation of transforming growth factor-beta (TGF-B) stimulates fibrotic and fat tissue in place of muscle. To date, the safest and most effective intervention for Chronic Inflammation is increasing the level of physical activity, which include aerobics, resistive, balance training and stretching or yoga". I explained elaborately.

"How does exercise help in preventing the chronic inflammation that you had mentioned?"

"As I told you, exercise is the only effective way to stabilize or prevent the cascade of heightened or chronic inflammation by decreasing NFkB activation and repressing inflammatory gene expression. Studies have suggested that increased CRP, IL6 and TNFRI are important predictors of cardio vascular and overall mortality in late life. There is a direct link between NFkB activation for the down regulation of a critical factor in skeletal muscle differentiation and repair in sarcopenia." [4].

I tried to explain it to him with a picture that how constant low-level or highgrade exercise can work in multiple levels to prevent chronic inflammation. Even we can claim that exercise is the best way to prevent ageing and age-related health issues [50] (Fig. 10.3).

The last step of MI is to address the patient's concern and use "strategies to improve understanding" slowly with verbal feedback from the patient which indicates he is able to understand the message.

"Sir, if you gradually increase your protein intake it would definitely improve your muscle mass, a balanced diet will increase your global function as well as enhance effort tolerance making you less tired even with a faster speed of walking from your house to court (500 meters). You can increase your gait speed gradually and modify your diet according to the advice of the dietician. It is a multimodal therapy for controlling sarcopenia, global functioning, and breathlessness from which you are suffering. Probably, it is the only solution at present. After all, you want to live a life with good Quality". I finally explained.

Mental practice is an effective way to learn a skill with minimal physical practice. Imagining an act and doing it are not as different as it might sound. When people close their eyes and visualize a simple object like letter A, the primary visual cortex lights up just as if the subject were looking at letter A. A brain scan would 


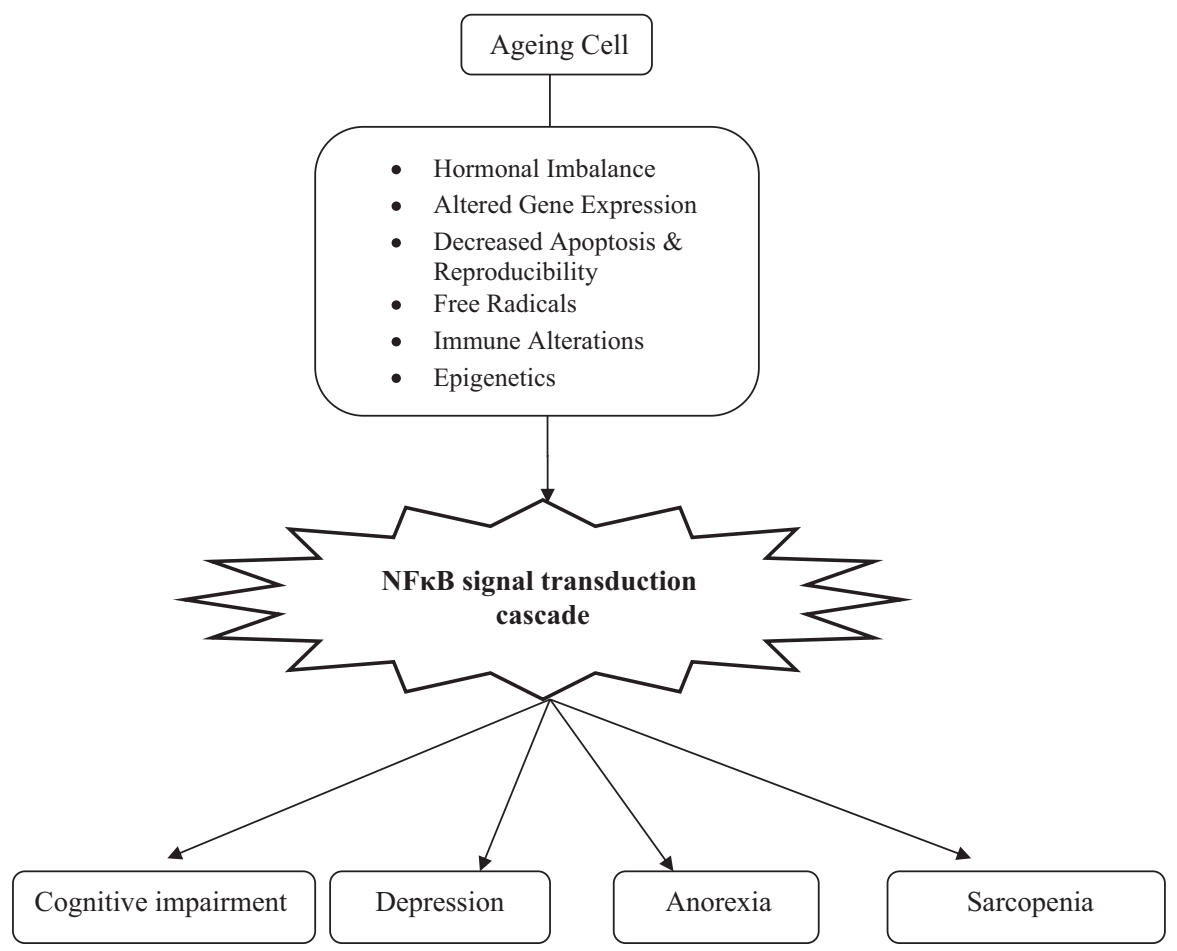

Fig. 10.3 Effects of chronic inflammation on ageing. (Source: Author)

show that in action and imagination, many of the same parts of the brain are activated. That is why visualization can improve performance. An experiment conducted by Yue and Cole [51] showed that imagining one is using one's muscle strengthens them. The study looked at two groups. One that did physical exercise and other that imagined that they are doing an exercise. Both groups exercised their finger muscles from Monday to Friday for 4 weeks. The physical group did trials of 15 maximal contractions with a 20 -s rest between each of them. The mental group imagined doing 15 muscle contractions with 20-s rest between each while also imagining a voice shouting at them "harder, harder, harder!" At the end of the study, the subjects who had done the physical exercise increased their muscular strength by $30 \%$, and as one might expect, those who only imagined doing the exercise for the same period increased their muscle strength by $22 \%$ [52].

The explanation lies in the motor neurons of the brain that program movements. During this imaginary contraction, the neuron responsible for shrinking together sequences of instrumentation instructions for movements is activated and strengthened, resulting in increased strength when the muscles are contracted.

He started improving his gait speed and the diet was instituted as suggested by the dietician. He came to me after 6 months and showed significant improvement in both functional and physical domains. 
So it is important to have a detailed discussion tailored to the subjects. One way of effective motivations for PA would be social coherence. Every colony could create their own elderly community to motivate each other. Associating with one's peer group along with positive interaction, encouragement and enjoyment as per an individual's ability would improve overall QOL.

\subsection{Lifelong Learning for Subjective Wellbeing}

Ms. Prerna Palta came to see me in 2014 and requested to address a gathering about active ageing. She was the president of senior citizen's association in Delhi that conducts health education talks at the end of every month. I visited their place on the evening of 27 September 2014. I was surprised to see there were almost 150 elderly people, heterogenous in their functional status-some were on wheelchair, few couples and singles. The younger group was standing behind as there were limited number of chairs. One common thing was that everyone had a smile on their faces that reflected their happiness. They cheerily wished, "Good evening Doctor", and I reciprocated with the same warmth. It was an interactive session on active ageing. I came to know from them that these 150 older individuals of their community were like a family. They shared each other's agony and happiness. They created a club and played badminton with an average age of 73 years which had been recorded in the Limca Book of Records. They also play carrom board and cards. They had appointed a physiotherapist who visited them every day, an alternative medicine doctor who took care of their problem. But most importantly, it was the social cohesiveness of that community which was helping to achieve successful ageing. They had diseases, familial and social issues, but there was a mechanism to absorb their problems - they had each other's support! Ms. Palta and her team met almost every day to discuss their issues and found a solution to it. They were meaningfully engaged in their own way. They tried to pursue physical activity for all, updating their medical knowledge, and also participated in advocacy to create better health policies. They went for excursions, even to temples together. In the pursuit of bringing value to their group, they had a very innovative thought to celebrate birthdays of members at the end of the month, even including the respective family members, which strengthened family bonds as well. Ms. Palta was very aggressive in dispelling the myths of ageism, such as ageing means disability, dependence and nonproductivity.

She told us, "Let us disrupt ageing by understanding and accepting age related limitations and exploring new possibilities using the wisdom of life".

This group was of lifelong learners. I tried to explain the theory of cumulative deficit model. If we compare our body with a vehicle, as a new vehicle getting old every day, then it is only a matter of questions like "how you maintain it", "driving it" with an average speed of $40-45 \mathrm{~km} / \mathrm{h}$, putting the right lubricant and servicing at regular intervals; all these would obviously keep our engine healthy. It matters very little whether longevity was in family gene, or whether you suffered a heart 
attack in your 50s. But what matters is how you respond to stress, your healthy/balanced diet, physical activity and less insult to your body, addiction and subjective wellbeing by ensuring good quality of living and social contribution. Stress leads to the release of hormones called glucocorticoid and kill cells in hippocampus. Recent commission published by lancet has found out middle life depression as a cause of dementia [53]. So you can change your attitude towards random events gradually at any age. You must balance between ambition and aspirations in social and familial context.

Learning new skills and new things is possible even at the age of 80 as older adults are often wiser and more socially adaptable than the young adults. Studies suggested that the elderly are less prone to depression than their younger counterparts.

Once my wife messaged me to pick our son Pratik from his art class while coming back home.

When I reached his class, with teacher's permission, I entered the classroom and saw the beautiful paintings which were hung on the wall at the entry, the lobby and in the classroom. When I was coming out of the classroom, I saw an elderly lady in the adjacent room sitting on a double cot bed with some back support making beautiful paintings. I entered the room after seeking her permission. She welcomed me with a heavenly smile.

"May I talk to you for a minute?" I asked and introduced myself. It is a very common phenomenon of the senior citizens of this country to be happy to interact with a doctor, especially when they understand that the interacting doctor is an elderly care physician that is a doctor "for them".

She smiled at me but not with much excitement like others, "Oh! Is there any specialist for us also?"

I asked, "Madam, are you the head teacher of this arts academy?" I thought she had transferred her legacy to the next generation.

"I am the student of my daughter", she answered confidently and with a lot of pride. She continued, "I have started learning 7 years ago, after I lost my hubby, I was 77 years then".

With a little hesitation I asked, "Madam would you mind telling me what inspired you to join painting?"

"Nothing. It was my wish to learn painting. But I was so busy throughout my life. My husband had a transferable job and I had to take care of my daughter. Once she settled, I had to take care of my husband. After his retirement I had to take care of my hubby exclusively. He was wheel chair bound and had multiple health problems".

This is not an uncommon scenario in our country where women sacrifice their desires initially for father, then for husband and children and then again for husband until death.

"After his death I was roaming here and then one day I met Mr. Ramesh Singh, a famous artist who does many kinds of art, sculpture. It was my dream since childhood to be an artist". She explained, "But you know doctor, I am not very creative like many. I can draw what I see. I draw from others' creativity. Ofcourse, I make 
some drawings from nature which is imprinted in my mind like the picture of my village which is intact in my visual memory".

She got excited as I was showing interest in her meaningful engagement. She started showing me more of her paintings done on glass, canvas, cardboards, etc.

Her daughter was very supportive and displayed her drawings in the classroom and the gallery of the academy. She was walking with a stick and had a lot of balance problem. In between she was placing her spectacles in right place over the nose. She had kyphoscoliosis (bending forward, sideways bending). She had tremor in her left hand but there was no dearth of enthusiasm. On further enquiry, I came to know that she had multiple morbidities like HTN, diabetes, hypothyroidism and cervical spondylitis which caused a lot of pain. In addition, she had been recently diagnosed with Parkinsonism. But all these medical problems did not bother her much because she was still learning new kinds of art from her guru. She was also learning computers to send emails and play basic games on the computer.

She would go for a morning walk as suggested by her doctor. She did not like the complex characters of TV serials or gossiping with the peer groups in the evening. In fact, if we analyse, Ms. Archana, without any knowledge of ageing process and medical science, kept on fulfilling her wishes and passions just like any student with a lot of aspiration to learn new things.

Cervical pain did not bother her as she was busy with her painting activity $5-6 \mathrm{~h}$ a day. Tremors could not stop her from holding the paint-brush as she was confident of doing something new. Age could not stop her from pursuing her passions in spite of multimorbidity. But there are people who have never exercised in this life neither they are doing it now. They and their family members are in illusion of complete retirement from job, meaningful engagement, and physical activity. Older adults of this country who are specially staying in joint family are regarded as respectable senior citizens of the family and are not meant to do any household activity either for the family or for the society.

With each passing day, gradually but steadily, they are losing their influence, autonomy, and independence along with significant functional and cognitive loss or intrinsic capacity.

They have to do expensive investigation for their small physical symptoms. They love to take a pill for every illness. They can gulp 20 medicines in a day, but won't walk 20 brisk steps in the park.

I remember Ms. Shyama Gupta, an 84-year-old lady who had practically no significant medical problem other than well-controlled HTN. She was from Gulmohar Park, one of the premier residential colonies of Delhi. She had visited multiple doctors for her intermittent tantrums and came back to me for the investigations as she was a CGHS beneficiary.

"Doctor, I have generalized weakness. My leg muscles are thin, and I have low grade fever although it does not show in the thermometer". She told me her problems.

When I examined her, there were no features of fever, sarcopenia or related diseases. But she suggested to me that she feels that she was suffering from some form 
of cancer. "Please write for me a PET MRI. I came to know from internet that this is the best test to detect cancer".

When I suggested her a year back and continuously counselled her about doing morning walk and take food in small quantities with more frequency, she was unwilling to follow the instructions. Her answer was "I have not done this, and I don't want to do it now. I do a lot of socialization with my peer group, but my morning starts at 11 in the morning".

It is a common problem among older adults, the inability to accept new ideas, and adopting those ideas in their daily routine needs a lot of cooperation from family members. It is important to have short-term, medium-term and long-term goal in consideration with health status of the individual.

Professor Jim et al. carried out a longitudinal survey in 1741 at the University of Pennsylvania for 20 years. They found that cumulative lifetime disability was four times greater in those who smoked, were obese and did not exercise. The onset of measurable disability was postponed by nearly 8 years in the lowest risk third of study participants compared with the highest risk third [54, 55].

Regular brisk walking and exercise reduce the chances of stroke by $27 \%$ and development of cancer of the colon, breast and uterus by $20 \%$ and prevent dementia by $40 \%[56,57]$.

Exercise also increases oxygen supply in the body and circulation, prevents depression by releasing endorphins in the bloodstream, reduces stress and anxiety and most importantly adds years to your life.

\subsection{To My Doctor and Paramedic Friends}

Doctors must think beyond conventional learning of disease or organ-specific diseases or symptoms when dealing with older adults. Clinician has to spend more time with older adults "who has many things" to say beyond obvious clinical signs. In fact, the clinical signs are mostly unusual/atypical. Atypical presentation is rather a rule than an exception in them. Understanding the mystery of ageing and tremendous individual variability mandates the clinician to approach the body as a whole. Life expectancy at that point of time, aspiration, goals, functionality and quality of life along with expectation of the patient from the doctor need special assessment before focusing on evidence-based disease centric care. Managing an octogenarian with global functional decline who attends the clinic of a doctor with recently diagnosed diabetes with a history of smoking for the past 30 years should not make the treating physician panic to manage diabetes whose life expectancy is less than 5 years, whereas the same clinical scenario presented at the age of 60 years mandates him to follow the evidence-based guidelines. 
I still remember Mr. Mahesh, a 75-year-old man, who was suffering from chronic heart failure (CHF), DM and HTN, well managed in the Department of Cardiology of a public hospital in Bihar. They were managing his multimorbidity for the past 20 years but never worked on his cognitive domain and never asked about the QOL. Mr. Mahesh, who had an excellent compliance towards drugs for CHF, recently had become forgetful. He had functional impairment in executing functioning, decline in mobility and two episodes of fall in which the treating doctors who were simply extrapolating his scheme of management both in the population with age more than 60 as well as in an octogenarian. CGA that is a quick head to foot assessment of an individual is mandatory when dealing with the old (aged $70-79$ years) and oldest old (80+) to find out geriatric syndromes like fall, frailty, urinary incontinence, functional decline, depression and dementia.

Multiple studies had concluded that CHF/COPD is no more disease related to the heart or lung alone. A study conducted by van Manen et al. reported that the prevalence of depression was $25 \%$ among patients with CHF [58]. COPD is known to be associated with the development of mild cognitive impairment, depression and sarcopenia [59, 60] and most importantly it compromises the quality of life [61]. The clinician must discuss about the expectation from the doctor which I did to $\mathrm{Mr}$. Mahesh. His first statement was "Doctor, I came from Bihar not to get treatment for my COPD, hypertension or diabetes which were well controlled, but I am not sure why I am feeling low, I am forgetful, and I want to be more energetic".

\subsection{To My Beloved Senior Citizens and Their Family Members}

Ageing is not a distinct phase of life which is disconnected from previous life stages. It must be seen as a continuum of life course availed in previous life stages. Successful ageing is a composite dynamic concept, influenced by few nonmodifiable factors like gene and environment, but mostly modifiable factors like diet, regular physical activity, personality, aspiration index (preparation), happiness quotient (life satisfaction), morbidity profile and subjective wellbeing.

The discussion in this book about ageing and Geriatric Medicine is not limited to those who are in their 60s, 70s or 80s; it is a preparation of whole life. After all you are fixing your destiny of happy and healthy ageing everyday starting from your birth and throughout your life course.

Our target is to accumulate a high intrinsic capacity (functional and cognitive capacity) in adolescence and middle life and maintain it in high tone as long as possible to achieve successful ageing (Fig. 10.4). 


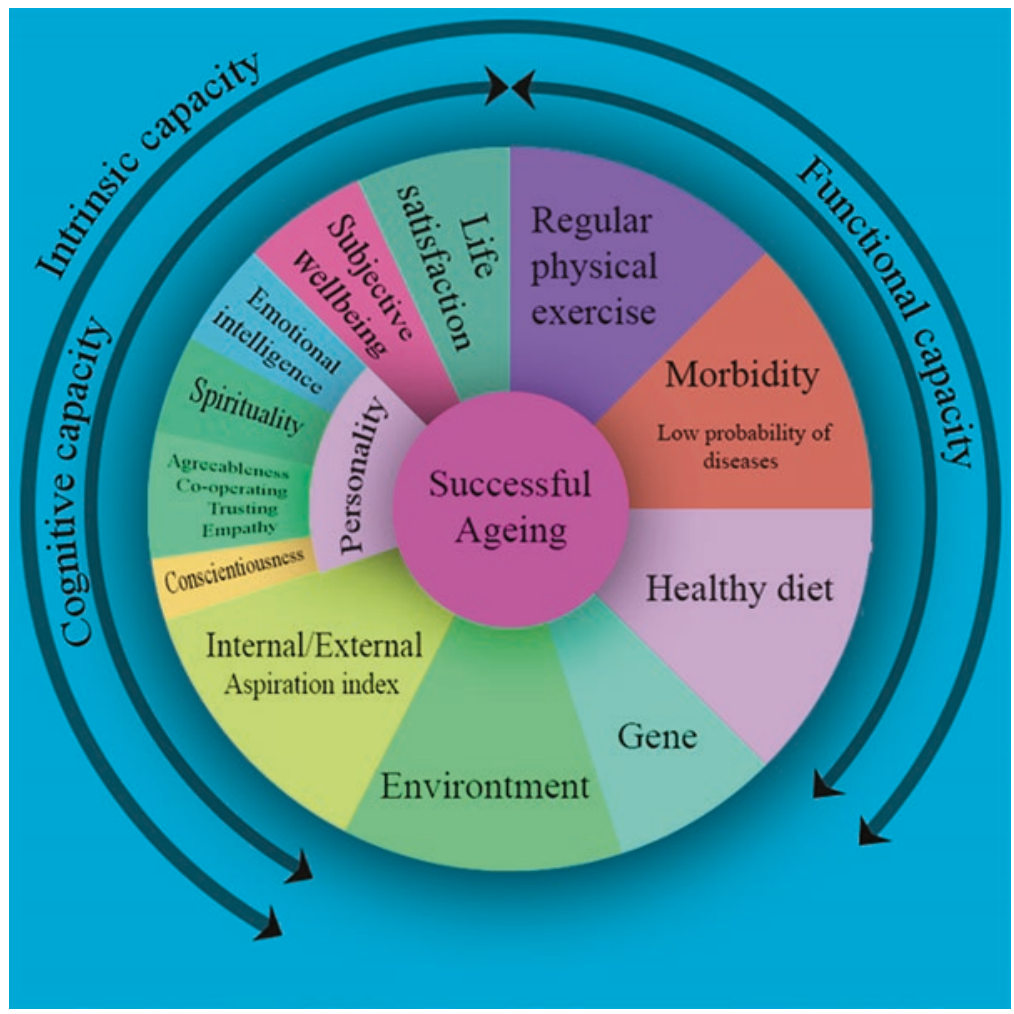

Fig. 10.4 Determinants of successful ageing. (Source: Author)

Small frequent plant-based natural diet, adequate protein are mandatory, which are not even very expensive. Low grade physical exercise in all form (aerobics, resistive, balance and stretching), but on regular basis, would help to keep chronic inflammation under control, thereby prevent disability, frailty and mortality. In this context, the peer group has a key role in motivating each other to achieve successful ageing.

I consider "ageing" as:

A-Active.

G-Genius as per Roman mythology. You are the "guardian spirit" of a place.

E-Empathetic. You understand other's problem more than any body.

I-Intelligent. You may have high emotional intelligence to understand your emotion and control it and channelize it towards positivity.

$\mathrm{N}-\mathrm{New}$ possibilities to explore your potential.

$\mathrm{G}-$ Geniality, i.e. you have the quality to be friendly with anybody in a cheerful manner through your life experience (Fig. 10.5).

Intergenerational solidarity is not only about a healthy relationship and exchange of love, care and respect for each other between two extreme generations but also a transfer of the legacy. 
Fig. 10.5 Components of emotional intelligence. (Source: https://www. verywellmind.com/ components-of-emotionalintelligence-2795438. [62])

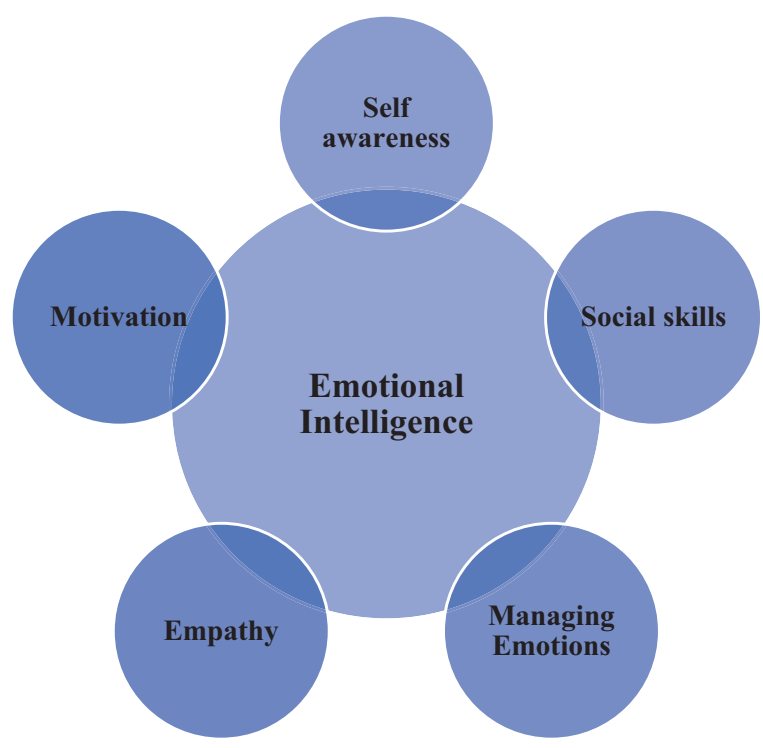

All of us are aware of death. But accepting it happily, to welcome it wholeheartedly, needs psychological and philosophical preparation. Every person, from the common man to an individual at the helm of success, wants to be immortalized. Parents would like to be immortalized through their children, and grandparents dream same for their grandchildren. We not only want to leave our footprints on this planet but also in the stars, with dignity, love and respect. But how many of us prepared to do so!

As the Nobel Laureate poet Rabindranath Tagore dreamt about himself after death, through his verses:

When my footsteps fall on this road no more

I will ferry not, my boat on this pier

I will end this buy and sell,

I will settle all my dues

I won't to and fro to this mart

So be it if you recall me or not

So be it if gazing up at the stars, you call me or not.

When dust accumulates

On the strings of the Tanpura*

When barbed fences of vines

Creep up doorways of home

When the flower garden adorns

Ascetic robes of dense green grass

When moss surrounds the pond

So be it if you recall me or not

So be it if gazing up at the stars, you call me or not.

Then will the flute still sing thus in this play

Days will pass, day after day

Just the way it does today 
Ferryboats will fill up that day

Piers full in the very same way

In that field, cows will graze, cowherds will play

So be it if you recall me or not

So be it if gazing up at the stars, you call me or not.

Who says then, I am no more, in that morn

In all play, this self will play

With a new name

In a new embrace

Come and go I will,

This self that is eternal

So be it if you recall me or not

So be it if gazing up at the stars, you call me or not.

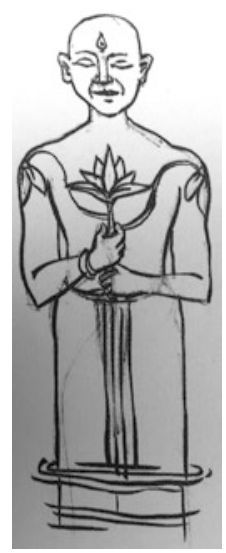

\section{References}

1. Flatt, M. A., Settersten, R. A., Ponsaran, R., \& Fishman, J. R. (2013). Are "anti-aging medicine" and "successful aging" two sides of the same coin? Views of anti-aging practitioners. The Journals of Gerontology Series B: Psychological Sciences and Social Sciences, 68(6), 944-955. https://doi.org/10.1093/geronb/gbt086.

2. Why I like the lazy way to longevity. Available at: https://timesofindia.indiatimes.com/blogs/ musings-from-the-mountains/why-i-like-the-lazy-way-to-longevity/. Accessed 8 Mar 2019.

3. Davidovic, M., Sevo, G., Svorcan, P., Milosevic, D. P., Despotovic, N., \& Erceg, P. (2010). Old age as a privilege of the "selfish ones". Aging and Disease, 1, 139-146.

4. Halter, J. B., Ouslander, J. G., Studenski, S., High, K. P., Asthana, S., Supiano, M. A., \& Ritchie, C. Hazzard's geriatric medicine and gerontology (p. 7e).

5. Mutha, P. K., Haaland, K. Y., \& Sainburg, R. L. (2012). The effects of brain lateralization on motor control and adaptation. Journal of Motor Behavior, 44(6), 455-469. https://doi.org/10.1 080/00222895.2012.747482.

6. Clark, B. C., Mahato, N. K., Nakazawa, M., Law, T. D., \& Thomas, J. S. (2014 December). The power of the mind: The cortex as a critical determinant of muscle strength/weakness. Journal of Neurophysiology, 112(12), 3219-3226. 
7. Cantor, N., \& Sanderson, C. A. (2003). Life task participation and wellbeing: The importance of taking part in daily life. In D. Kahneman, E. Diener, \& N. Schwarz (Eds.), Well-being: the foundation of hedonic psychology (pp. 230-243). New York: Russel Sage Foundation.

8. Berg, J. L. (2015). The role of personal purpose and personal goals in symbiotic visions. Frontiers in Psychology, 6, 443. https://doi.org/10.3389/fpsyg.2015.00443.

9. American Diabetes Association. (2018). 11. Older adults: Standards of medical care in diabetes-2018. Diabetes Care, 41(Suppl. 1), S119-S125.

10. NPS Medicinewise. (2015). Sleeping pills and older people: The risks. Available at: https:// www.nps.org.au/medical-info/clinical-topics/news/sleeping-pills-and-older-people-the-risks. Accessed 7 Feb 2018.

11. Srinivasan, V., Cardinali, D. P., Srinivasan, U. S., Kaur, C., Brown, G. M., Spence, D. W., Hardeland, R., \& Pandi-Perumal, S. R. (2011). Therapeutic potential of melatonin and its analogs in Parkinson's disease: Focus on sleep and neuroprotection. Therapeutic Advances in Neurological Disorders., 4(5), 297-317. https://doi.org/10.1177/1756285611406166.

12. Mack, J. M., Schamne, M. G., Sampaio, T. B., et al. (2016). Melatoninergic system in Parkinson's disease: From neuroprotection to the management of motor and nonmotor symptoms. Oxidative Medicine and Cellular Longevity, 2016, 3472032.

13. Baltes, P. B., \& Smith, J. (2003). New frontiers in the future of aging: From successful aging to the young old to the dilemmas of the fourth age. Gerontology (Behav Sci), 49, 123-135.

14. Goleman, D. (2011). The brain and emotional intelligence. Northampton: More Than Sound.

15. Silva, F., Iop, R., Arancibia, B., Ferreira, E., Hernandez, S., \& Silva, R. (2016). Effects of Nordic walking on Parkinson's disease: A systematic review of randomized clinical trials. Fisioterapia e Pesquisa, 23(4), 439-447.

16. Tomlinson, C. L., Herd, C. P., Clarke, C. E., Meek, C., Patel, S., Stowe, R., Deane, K. H. O., Shah, L., Sackley, C. M., Wheatley, K., \& Ives, N. (2014). Physiotherapy for Parkinson's disease: A comparison of techniques. Cochrane Database of Systematic Reviews, (6), CD002815. https://doi.org/10.1002/14651858.CD002815.pub2.

17. Kasser, T., \& Ryan, R. M. (1993). A dark side of the American dream: Correlates of financial success as a central life aspiration. Journal of Personality and Social Psychology, 65, 410-422.

18. Ryan, R. M., Chirkov, V. I., Little, T. D., Sheldon, K. M., Timoshina, E., \& Deci, E. L. (1999). The American dream in Russia: Extrinsic aspirations and well-being in two cultures. Personality and Social Psychology Bulletin, 25, 1509-1524.

19. Costa, P. T., Jr., \& McCrae, R. R. NEO PI-R professional manual 1992. Odessa: FL Psychological Assessment Resources, Inc.

20. Shock, N. W., Greulich, R. C., Costa, P. T., Jr., Andres, R., Lakatta, E. G., \& Arenberg, D. (1984). Normal human aging: The Baltimore longitudinal study on aging. Washington, DC: NIH Publication.

21. Terracciano, A., Sanna, S., Uda, M., et al. (2010). Genome-wide association scan for five major dimensions of personality. Molecular Psychiatry, 15(6), 647-656. https://doi.org/10.1038/ mp.2008.113.

22. Srivastava, K., \& Das, R. C. (2013). Personality pathways of successful ageing. Industrial Psychiatry Journal, 22(1), 1-3. https://doi.org/10.4103/0972-6748.123584.

23. Cloninger, C. R., Svrakic, D. M., \& Przybeck, T. R. (1993). A psychobiological model of temperament and character. Archives of General Psychiatry, 50(12), 975-990.

24. Aoki, J., Ikeda, K., Murayama, O., Yoshihara, E., Ogai, Y., \& Iwahashi, K. (2010). The association between personality, pain threshold and a single nucleotide polymorphism (rs3813034) in the 3'-untranslated region of the serotonin transporter gene (SLC6A4). Journal of Clinical Neuroscience, 17(5), 574-578. 
25. Pilling, L. C., Harries, L. W., Powell, J., Llewellyn, D. J., Ferrucci, L., \& Melzer, D. (2012). Genomics and successful aging: Grounds for renewed optimism? The Journals of Gerontology Series A: Biological Sciences and Medical Sciences, 67A(5), 511-519. https://doi.org/10.1093/ gerona/gls091.

26. Dan Buettner. (2017). Blue zones lessons from the world's blue zones on living a long, healthy life. Available at: https://www.weforum.org/agenda/2017/06/changing-the-way-america-eatsmoves-and-connects-one-town-at-a-time/7. Accessed 7 Feb 2018.

27. Koene, R. J., Prizment, A. E., Blaes, A., \& Konety, S. H. (2016). Shared risk factors in cardiovascular disease and Cancer. Circulation, 133(11), 1104-1114.

28. Pem, D., \& Jeewon, R. (2015). Fruit and vegetable intake: Benefits and progress of nutrition education interventions- narrative review article. Iranian Journal of Public Health, 44(10), $1309-1321$.

29. NHS. (2017). Grandparents who babysit 'tend to live longer'. Available at: https://www.nhs. uk/news/older-people/grandparents-who-babysit-tend-to-live-longer/. Accessed 7 Feb 2018.

30. Roberson, R. (2017). Why People in "Blue Zones" live longer than the rest of the world. Available at: https://www.healthline.com/nutrition/blue-zones\#section5. Accessed 7 Feb 2018.

31. WHO. (2018). Global strategy on diet, physical activity and health physical activity and adults. Available at: https://www.who.int/dietphysicalactivity/factsheet_adults/en/. Accessed 7 Feb 2018.

32. Arem, H., Moore, S. C., Patel, A., Hartge, P., Berrington de Gonzalez, A., Visvanathan, K., Campbell, P. T., et al. (2015). Leisure time physical activity and mortality: A detailed pooled analysis of the dose-response relationship. JAMA Internal Medicine, 175(6), 959-967. https:// doi.org/10.1001/jamainternmed.2015.0533.

33. Atchlet, R. C. (2011). How spiritual experience and development interact with aging. The Journal of Transpersonal Psychology, 41(2), 156-165.

34. Hinchliff, S., Norman, S., \& Schober, J. (2008). Nursing practice and health care 5E. Hodder Education.

35. Harrington, A. (2016). The importance of spiritual assessment when caring for older adults. Aging and Society, 36(1), 1-16.

36. Chiu, L., Emblem, J. D., Van Hofwegen, L., Sawatzky, R., \& Meyerhoff, H. (2004). An integrative review of the concept of spirituality in the health sciences. Western Journal of Nursing Research, 26(4), 405-426.

37. Walker, A. (2005). A European perspective on quality of life in old age. European Journal of Ageing, 2(1), 2-12. https://doi.org/10.1007/s10433-005-0500-0.

38. Tiwari, S. C., \& Pandey, N. M. (2013). The Indian concepts of lifestyle and mental health in old age. Indian Journal of Psychiatry, 55(Suppl 2), S288-S292. https://doi. org/10.4103/0019-5545.105553.

39. Belza, B., Walwick, J., Shiu-Thornton, S., Schwartz, S., Taylor, M. L., \& Gerfo, J. (2004). Older adult perspective on physical activity and exercise: Voices from multiple cultures. Preventing Chronic Disease, 1-12. Available at: http://www.cdc.gov/pcd/issues/2004/oct/04_0028.htm. Accessed 7 Feb 2018.

40. Melillo, K. D., Futrell, M., Williamson, E., Chamberlain, C., Bourque, A. M., MacDonnell, M., \& Phaneuf, J. P. (1996). Perceptions of physical fitness and exercise activity among older adults. Journal of Advanced Nursing, 23, 542-547.

41. Reach, D. C. Barriers to physical activity in older adults with implications for practice. https://research.wsulibs.wsu.edu/xmlui/bitstream/handle/2376/4195/d_reach_011023300. pdf? sequence=1. Accessed 7 Feb 2018. 
42. Dergance, J. M., Calmbach, W. L., Dhanda, R., Miles, T. P., Hazunda, H. P., \& Mouton, C. P. (2003). Barriers to and benefits of leisure time physical activity in the elderly: Differences across cultures. Journal of American Geriatric Society, 51, 863-868.

43. Cohen-Mansfield, J., Marx, M. S., \& Guralnik, J. M. (2003). Motivators and barriers to exercise in an older community-dwelling population. Journal of Aging and Physical Activity, 11, 242-253.

44. Rollnick, S., Miller, W. R., \& Butler, C. C. (2008). Motivational interviewing in healthcare: Helping patients change behavior. New York: The Guilford Press.

45. Cummings, S. M., Cooper, R. L., \& Cassie, K. M. (2009). Motivational interviewing to affect behavioral change in older adults. Research on Social Work Practice, 19, 195-204.

46. Resnicow, K., Jackson, A., Blissett, D., Wang, T., McCarty, F., Rahotep, S., \& Periasamy, S. (2015). Results of the healthy body healthy spirit trial. Health Psychology, 24(4), 339-348.

47. IOM (Institute of Medicine). (2002). Dietary reference intakes for energy, carbohydrates, fiber, fat, fatty acids, cholesterol, protein, and amino acids. Washington, DC: National Academies Press.

48. Fulgoni, V. L. (2008). Current protein intake in America: Analysis of the national health and nutrition examination survey, 2003-2004. The American Journal of Clinical Nutrition, 87, $1554 \mathrm{~S}-1557 \mathrm{~S}$.

49. García-Arias, M. T., Rodrígues, A. V., García-Linares, M. C., Rocandio, A. M., \& Gar-cíaFernández, M. C. (2003). Daily intake of macronutrients in a group of institutionalized elederly people in León, Spain. Nutrición Hospitalaria, 18, 87-90.

50. Ciolac, E. G. (2013). Exercise training as a preventive tool for age-related disorders: A brief review. Clinics, 68(5), 710-717. https://doi.org/10.6061/clinics/2013(05)20.

51. Yue, G., \& Cole, K. J. (1992). Strength increases from the motor program: Comparison of training with maximal voluntary and imagined muscle contractions. Journal of Neurophysiology, $67,1114-1123$.

52. Doidge, N. (2010). The brain that changes itself: Stories of personal triumph from the frontiers of brain science. Carlton North: Scribe Publications.

53. Preparing for later life today. The Lancet. 2017 390(10093), 429. Available at http://www. thelancet.com/pdfs/journals/lancet/PIIS0140-6736(17)31996-7.pdf. Accessed 7 Feb 2018.

54. Vita, A. J., Terry, R. B., Hubert, H. B., \& Fries, J. F. (1998). Aging, health risks, and cumulative disability. The New England Journal of Medicine, 338, 1035-1041.

55. Swartz, A. (2008). Fries J. Healthy aging pioneer. American Journal of Public Health, 98(7), 1163-1166. https://doi.org/10.2105/AJPH.2008.135731.

56. Garatachea, N., Pareja-Galeano, H., Sanchis-Gomar, F., Santos-Lozano, A., Fiuza-Luces, C., et al. (2015). Exercise attenuates the major hallmarks of aging. Rejuvenation Research, 18(1), $57-89$.

57. Trimarchi, M. How much vitamin D do you get from the sun? Available from: https://health. howstuffworks.com/wellness/food-nutrition/vitamin-supplements/how-much-vitamin-dfrom-sun.htm. Accessed 7 Feb 2018.

58. van Manen, J. G., Bindels, P., Dekker, F., IJzermans, C., van der Zee, J. S., Schade, E., et al. (2002). Risk of depression in patients with chronic obstructive pulmonary disease and its determinants. Thorax, 13, 412-416.

59. Singh, B., Mielke, M. M., Parsaik, A. K., et al. (2014). A prospective study of chronic obstructive pulmonary disease and risk of mild cognitive impairment. JAMA Neurology, 71(5), 581588. https://doi.org/10.1001/jamaneurol.2014.94.

60. Byun, M. K., Cho, E. N., Chang, J., Ahn, C. M., \& Kim, H. J. (2017). Sarcopenia correlates with systemic inflammation in COPD. International Journal of Chronic Obstructive Pulmonary Disease, 12, 669-675. https://doi.org/10.2147/COPD.S130790. 
61. Al Moamary, M. S., Tamim, H. M., Al-Mutairi, S. S., Al-Khouzaie, T. H., Mahboub, B. H., Al-Jawder, S. E., Alamoudi, O. S., \& Al Ghobain, M. O. (2012). Quality of life of patients with chronic obstructive pulmonary disease in the Gulf Cooperation Council countries. Saudi Medical Journal, 33(10), 1111-1117.

62. Cherry, K. (2018). Five components of emotional intelligence 03, 2018. Available at: https:// www.verywellmind.com/components-of-emotional-intelligence-2795438. Accessed 8 Mar 2019

Open Access This chapter is licensed under the terms of the Creative Commons Attribution 4.0 International License (http://creativecommons.org/licenses/by/4.0/), which permits use, sharing, adaptation, distribution and reproduction in any medium or format, as long as you give appropriate credit to the original author(s) and the source, provide a link to the Creative Commons license and indicate if changes were made.

The images or other third party material in this chapter are included in the chapter's Creative Commons license, unless indicated otherwise in a credit line to the material. If material is not included in the chapter's Creative Commons license and your intended use is not permitted by statutory regulation or exceeds the permitted use, you will need to obtain permission directly from the copyright holder.

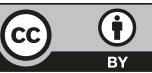

